\title{
Analysis of a thermal cluster
}

At the crossroads of medical tourism and wellness: the case of INNOVATHERM (or Auvergne thermal innovation)

\section{Nathalie Montargot and Marie-Eve Férérol}

\section{(2) OpenEdition}

Journals

Electronic version

URL: http://journals.openedition.org/rfst/809

DOI: $10.4000 /$ rfst.809

ISSN: 2492-3672

\section{Publisher}

Espaces et SOciétés (UMR 6590)

\section{Electronic reference}

Nathalie Montargot and Marie-Eve Férérol, "Analysis of a thermal cluster", Revue francophone sur la santé et les territoires [Online], Tourism, Mobility and Health, Online since 25 October 2016, connection on 06 April 2021. URL: http://journals.openedition.org/rfst/809 ; DOI: https://doi.org/10.4000/rfst.809

This text was automatically generated on 6 April 2021.

\section{(c) (i) (2)(2)}

La Revue francophone sur la santé et les territoires est mise à disposition selon les termes de la Licence Creative Commons Attribution - Pas d'Utilisation Commerciale - Partage dans les Mêmes Conditions 4.0 International. 


\title{
Analysis of a thermal cluster
}

\author{
At the crossroads of medical tourism and wellness: the case of \\ INNOVATHERM (or Auvergne thermal innovation)
}

Nathalie Montargot and Marie-Eve Férérol

1 Historically, French thermalism has experienced a succession of ups and downs. At the end of the Second World War, crenotherapy became a regulated sector. In connection with this evolution, the thermal traffic exploded. A growth of $150 \%$ in 40 years is noticeable: from 250,000 insured patients (in French Assurés Sociaux: AS) in the 1950s to more than 630,000 in 1988. Unfortunately, this progression is an illusion. The democratization of hydrotherapy has certainly generated significant flows in the resorts, but the new clientele has much lower incomes than those of the previous decades. In this context of radicalization of the thermal doctrine, French elites are now opting to visit resorts located in Central Europe and Italy. The period of growth in use of French hydrotherapy destinations peaked in 1988. A phase of "obscurantism", to use Jamot 's (2008) expression, started thereafter. At the end of the 1980s, water towns faced several problems, often linked declines in visitors. For a long time, they had an dedicated clientele; spa professionals, such as tourism operators, did not feel the need to invest to modernize their equipment, letting them age. At the same time, the resorts, in line with the Social Security system, had overemphasized their curative aspect, forgetting what made them successful in the 19th century. The result was a poor image: cities of patients, boring, with outdated facilities. Other factors also explain the decline of French thermalism (almost disappearance of "hydrology" training in universities, better effectiveness of drugs for certain diseases, competition from thalassotherapy centres and foreign countries, etc). In 2009, the number of patients AS was the lowest since the 1970s: 486,723. Since then, it has been slowly rising to reach 590,000 in $2016++$ $21 \%$ in seven years). A new phase, bringing hope, has started. It is in this context of economic upturn that the Auvergne (our research ground) launched itself in 2013 in a thermal cluster.

2 Few researchers are interested in spas and thermal resorts, and an even smalerl number work on tourism clusters. Their study started late, in the 2000s, with the works of Fabry (2009), Botti (2011) and Clergeau and Violier (2011). Their interest is essential. 
"The development of clusters in tourism is relatively recent, but is particularly relevant, insofar as it is the territory, the destination that support the economic development of tourism" (Bacchus and Coltier, 2013: 10). For a long time reserved for the industrial sector alone, the term cluster is increasingly used in the management of tourist destinations. This term refers to the geographical concentration of companies in the same sector, engaged in a process that is as much about cooperation as it is about competition. In 2013, the thermal resorts of Auvergne chose this approach to intensify their cooperation, in order to improve their competitiveness and attractiveness. This case study has a triple interest. It firstly enriches discussions around the notion of innovation, by seeking to understand to understand the principles of governance and innovation within a cluster of a particular kind. Indeed, only two thermal clusters exist in France. It is also a question of taking an interest in an economic sector that has been booming in recent years and showing how spas, beyond representations, capitalize on their assets, innovate and develop new products. Finally, this case is innovative in its theme, because few researchers in social sciences study the spa industry.

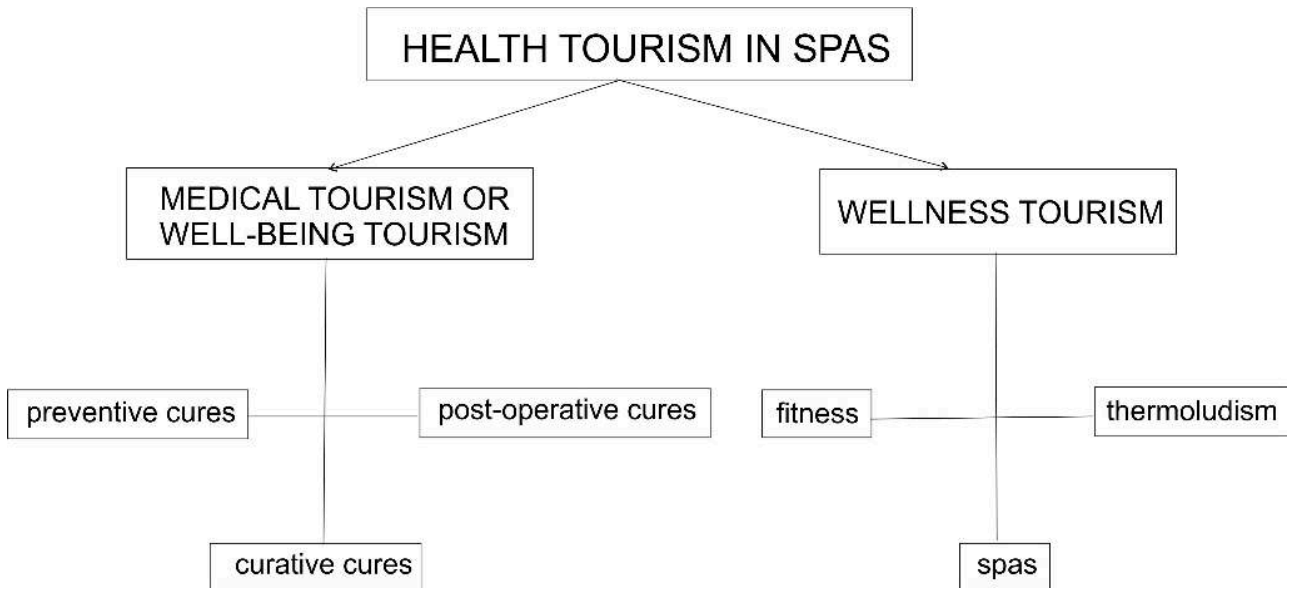

INDEX

Keywords: spas, hydrotherapy, medical tourism, tourism

Geographical index: Auvergne Rhône-Alpes

\section{AUTHORS}

\section{NATHALIE MONTARGOT}

Docteur en sciences de gestion, La Rochelle Business School-excelia group, CEREGE EA1722

\section{MARIE-EVE FÉRÉROL}

Docteur en géographie (Doctorat obtenu à Clermont II), qualifiée maître de conférences en géographie-aménagement 